\title{
EFEK MODEL PEMBELAJARAN INQUIRY TRAINING MENGGUNAKAN MEDIA PhET TERHADAP KETERAMPILAN PROSES SAINS DAN KEMAMPUAN BERPIKIR LOGIS SISWA
}

\author{
Fajrul Wahdi Ginting dan Nurdin Bukit \\ Jurusan Pendidikan Fisika Program Pascasarjana Universitas Negeri Medan \\ Email: fwginting@gmail.com
}

\begin{abstract}
Abstrak. Penelitian ini bertujuan untuk menganalisis: keterampilan proses sains dan kemampuan berpikir logis siswa yang menggunakan model pembelajaran inquiry training menggunakan media PhET; keterampilan proses sains dan kemampuan berpikir logis siswa yang menggunakan model pembelajaran konvensional; dan perbedaan keterampilan proses sains dan kemampuan berpikir logis siswa yang menggunakan model pembelajaran Inquiry Training menggunakan media PhET dan model pembelajaran konvensional. Penelitian ini merupakan penelitian quasi eksperimen. Pemilihan sampel dilakukan dengan teknik cluster random sampling sebanyak dua kelas yaitu kelas VIII-E dan kelas VIII-B, dimana kelas VIII-E diajarkan dengan model pembelajaran Inquiry Training menggunakan media PhET dan kelas VIII-B dengan pembelajaran konvensional. Instrumen yang digunakan terdiri dari tes keterampilan proses sains berupa tes essay dan tes kemampuan berpikir logis berupa tes pilihan berganda. Data dalam penelitian ini dianalisis dengan menggunakan uji t. Hasil penelitian menunjukkan bahwa keterampilan proses sains fisika yang menggunakan model pembelajaran Inquiry Training menggunakan media PhET berbeda dan menunjukkan hasil yang lebih baik dibandingkan dengan pembelajaran konvensional, dan kemampuan berpikir logis siswa yang menggunakan model pembelajaran Inquiry Training menggunakan media PhET berbeda dan menunjukkan hasil yang lebih baik dibandingkan dengan pembelajaran konvensional, serta terdapat perbedaan antara kemampuan berpikir logis dan keterampilan proses sains siswa yang menggunakan model pembelajaran Inquiry Training menggunakan media PhET dan model pembelajaran konvensional.
\end{abstract}

Kata kunci: inquiry training, media PhET, keterampilan proses sains, kemampuan berpikir logis

\section{THE EFFECT OF INQUIRY TRAINING MODEL USE THE MEDIA PHET AGAINST SCIENCE PROCESS SKILLS AND LOGICAL THINKING SKILLS STUDENTS}

\author{
Fajrul Wahdi Ginting dan Nurdin Bukit \\ Program of Physics Education Graduate Program, State University of Medan \\ Email: fwginting@gmail.com
}

\begin{abstract}
The Purpose of The study: science process skills and logical thinking ability of students who use inquiry learning model training using PhET media; science process skills and logical thinking ability of students who use
\end{abstract}


conventional learning model; and the difference science process skills and logical thinking ability of students to use learning model Inquiry Training using PhET media and conventional learning models. This research is a quasi experimental. Sample selection is done by cluster random sampling are two classes of classes VIII-E and class VIII-B, where the class VIII-E is taught by inquiry training model using media PhET and VIII-B with conventional learning model. The instrument used consisted of tests science process skills such as essay tests and tests of the ability to think logically in the form of multiple-choice tests. The data were analyzed using $t$ test. The results showed that physics science process skills use Inquiry Training models using PhET media is different and showed better results compared with conventional learning model, and logical thinking skills students use Inquiry Training model using PhET media is different and show better results compared with conventional learning, and there is a difference between the ability to think logically and science process skills of students who use Inquiry Training model using PhET media and conventional learning models.

Keywords: Inquiry training, PhET media, science process skills, logical thinking skills

\section{PENDAHULUAN}

Pendidikan IPA (Sains) adalah salah satu aspek pendidikan yang digunakan sebagai alat untuk mencapai tujuan pendidikan. Dalam pendidikan sains tersebut tidak hanya terdiri dari fakta, konsep, dan teori yang dapat dihafalkan, tetapi juga terdiri atas kegiatan atau proses aktif menggunakan pikiran dan sikap ilmiah dalam mempelajari gejala alam yang belum diterangkan. Rao (2012) mengungkapkan bahwa sains memiliki ciri-ciri tertentu, beberapa ciri sains diantaranya memiliki objek kajian berupa benda-benda konkret, mengembangkan pengalaman empiris, menggunakan langkah-langkah sistematis, menggunakan cara berpikir logis, dan hukum-hukum yang dihasilkan bersifat universal. Belajar sains merupakan suatu proses psikologis berupa tindakan atau upaya seseorang untuk mengkonstruksi dan memahami suatu gejala alam.

Sebagai hasil belajar diharapkan siswa memiliki kemampuan berfikir dan bertindak berdasarkan pengetahuan sains yang dimilikinya melalui kerangka berfikir sains. Seperti yang disarankan oleh Bruner dalam Trianto (2009) agar siswa-siswa hendaknya belajar melalui partisipasi secara aktif dengan konsepkonsep dan prinsip-prinsip, agar mereka dianjurkan untuk memperoleh pengalaman dan melakukan eksperimen-eksperimen yang mengizinkan mereka untuk menemukan prinsipprinsip itu sendiri.

Beberapa penelitian pembelajaran berbasis konstruktivis telah dilakukan untuk melihat efektivitasnya dalam mengkonstruksi pengetahuan oleh siswa sendiri dalam menumbuhkan sikap ilmiah dan kemampuan berpikir logis. Hal ini dilakukan sesuai pendapat Bruner (Dahar, 1991) bahwa selama kegiatan belajar berlangsung hendaknya siswa dibiarkan mencari atau menemukan sendiri makna segala sesuatu yang dipelajari.

Berdasarkan hasil dari wawancara dengan seorang guru fisika di SMP Negeri 40 Medan, diperoleh nilai rata-rata hasil ujian fisika semester genap tahun ajaran 2013/2014 sekitar 60 dengan KKM yang ditetapkan sekolah sebesar 70. Dari wawancara dengan guru yang bersangkutan juga didapatkan bahwa kurangnya variasi model pembelajaran yang diterapkan. Model pembelajaran yang selama ini paling sering diterapkan adalah model pembelajaran 
Direct Instruction. Model pembelajaran yang selama ini digunakan tidak membuat siswa berpartisipasi secara aktif sehingga kurang memberikan kesempatan pada siswa untuk ikut menghayati proses penemuan dan penyusunan suatu konsep sebagai suatu keterampilan proses.

Menurut Joyce (2011) model pembelajaran Inquiry Training dirancang untuk membawa siswa secara langsung ke dalam proses ilmiah melalui latihan-latihan yang dapat memadatkan proses ilmiah tersebut ke dalam waktu yang singkat. Tujuannya adalah membantu siswa mengembangkan disiplin dan keterampilan intelektual yang diperlukan untuk mengajukan pertanyaan dan menemukan jawabannya berdasarkan rasa keingintahuannya. Joyce (2011) mengungkapkan salah satu dampak instruksional dari penerapan model pembelajaran inquiry training adalah keterampilan proses sains siswa.

Keterampilan proses dapat diartikan sebagai keterampilan-keterampilan intelektual, sosial dan fisik yang bersumber dari kemampuan-kemampuan mendasar yang pada prinsipnya telah ada dalam diri siswa (Dimyati dan Mudjiono, 2009). Pada pembelajaran fisika dapat dilakukan penerapan metode praktikum untuk membentuk keterampilan proses pada siswa. Seperti yang diuraikan oleh Sani (2012) bahwa pelaksanaan praktikum juga bermanfaat dalam pembentukan keterampilan proses yang dibutuhkan oleh siswa untuk menyelesaikan permasalahan fisika kontekstual.

Joyce (2011) juga mengungkapkan salah satu dampak pengiring dari penerapan model pembelajaran inquiry training adalah kemampuan berpikir logis pada siswa. Berfikir logis adalah suatu proses menalar tentang suatu objek dengan cara menghubungkan serangkaian pendapat untuk sampai kepada sebuah kesimpulan menurut aturan-aturan logika. Rohman (2014) mengungkapkan bahwa logika mensyaratkan adanya tiga hal sebagai komponen berfikir logis. Ketiga hal tersebut meliputi; (1) Pengertian (concept). (2) Keputusan (decision). (3) Penalaran (reasoning).
Implementasi model pembelajaran Inquiry Training baik untuk peningkatan hasil belajar dan maupun proses berpikir seperti yang telah diteliti sebelumnya oleh Damanik (2013) menyimpulkan bahwa model pembelajaran Inquiry Training efektif dalam peningkatan hasil belajar siswa dibandingkan dengan model pembelajaran konvensional. Dari penelitian sebelumnya yang dilakukan oleh Legimin (2010) terdapat perbedaan yang signifikan antara hasil belajar siswa yang memiliki keampuan berikir logis rendah dan kemampuan berpikir logis tinggi. Sutama (2014) menunjukkan bahwa keterampilan berpikir kritis kelompok siswa yang mendapat model pembelajaran inkuiri lebih baik dibandingkan dengan kelompok siswa yang mendapat pembelajaran dengan model pembelajaran langsung, dan juga terdapat perbedaan kinerja ilmiah antara siswa yang mengikuti model pembelajaran inkuiri dengan siswa yang mengikuti pembelajaran dengan model pembelajaran langsung. Purwanto (2012) mengungkapkan terdapat perbedaan hasil belajar fisika siswa dengan menerapkan model inquiry training dan hasil belajar siswa yang menerapkan model konvensional.

\section{METODE PENELITIAN}

Populasi dalam penelitian ini adalah semua siswa kelas VIII SMP Negeri 40 Medan pada Tahun Pelajaran 2014/2015 dengan jumlah 7 (tujuh) kelas. Sampel dalam penelitian ini diambil secara cluster random sampling sebanyak dua kelas, yaitu kelas eksperimen dengan menggunakan model Inquiry Training menggunakan media PhET sebanyak 34 siswa dan kelas kontrol dengan menggunakan model konvensional sebanyak 34 siswa.

Dalam penelitian ini, pemeliti menggunakan 2 variabel yakni, variabel bebas dan variabel terikat. Variabel bebas dalam penelitian ini adalah model pembelajaran Inquiry Training dengan menggunakan media PhET dan pembelajaran konvensional. Variabel terikat dalam penelitian ini adalah keterampilan proses sains dan kemampuan berpikir logis siswa. Desain penelitian pada penelitian ini adalah 
control group pretest-postest design seperti pada Tabel 1.

Tabel 1. Desain Penelitian Control Group Pretest-Postest Design

\begin{tabular}{lccc}
\hline \multicolumn{1}{c}{ Kelas } & Pretest & Perlakuan & Postest \\
\hline Eksperimen & $\mathrm{Y}_{1}$ & $\mathrm{X}_{1}$ & $\mathrm{Y}_{2}$ \\
Kontrol & $\mathrm{Y}_{1}$ & $\mathrm{X}_{2}$ & $\mathrm{Y}_{2}$ \\
\hline
\end{tabular}

$\mathrm{X}_{1}=$ Pembelajaran dengan model pembelajaran inquiry training menggunakan media PhET.

$\mathrm{X}_{2}=$ Pembelajaran dengan model pembelajaran konvensional.

$\mathrm{Y}_{1}=$ Pretes yang diberikan sebelum adanya perlakuan pada kelas eksperimen dan kelas kontrol.

$\mathrm{Y}_{2}=$ Postes yang diberikan setelah adanya perlakuan pada kelas eksperimen dan kelas kontrol.

\section{HASIL PENELITIAN DAN PEMBAHASAN}

Pada tahapan awal penelitian, kelas eksperimen dan kelas kontrol diberikan pretes keterampilan proses sains dan pretes kemampuan berpikir logis. Data hasil pretes dapat dilihat pada Tabel 2.

Tabel 2. Data Pretes

\begin{tabular}{ccc}
\hline Hasil Pretes & Kelompok & Rerata \\
\hline Keterampilan & Eksperimen & 30,68 \\
\cline { 2 - 3 } Proses Sains & Kontrol & 30,62 \\
\hline Kemampuan & Eksperimen & 50,29 \\
\cline { 2 - 3 } Berpikir Logis & Kontrol & 51,47 \\
\hline
\end{tabular}

Selanjutnya dilakukan uji prasyarat hipotesis data pretes. Uji prasyarat hipotesis meliputi uji normalitas dengan uji Kolmogorov-Smirnov dan uji homogenitas menggunakan bantuan SPSS 16.0. Data hasil uji normalitas pretes dapat dilihat pada Tabel 3 .

Tabel 3. Uji Normalitas Data Pretes

\begin{tabular}{lcc}
\hline \multicolumn{1}{c}{ Uji Normalitas } & Sig. & Keterangan \\
\hline KPS Eksperimen & 0,200 & Normal \\
\hline KBL Eksperimen & 0,132 & Normal \\
\hline KPS Kontrol & 0,060 & Normal \\
\hline KBL Kontrol & 0,135 & Normal \\
\hline
\end{tabular}

Data hasil uji homogenitas pretes dapat dilihat pada Tabel 4.
Tabel 4. Uji Homogenitas Data Pretes

\begin{tabular}{lcc}
\hline Uji Homogenitas & Sig. & Keterangan \\
\hline Pretes KPS & 0,816 & Homogen \\
\hline Pretes KBL & 0,977 & Homogen \\
\hline
\end{tabular}

Selanjutnya pengujian kesamaan hasil pretes kedua kelompok sampel dengan uji-t melalui bantuan SPSS 16.0 menggunakan Independent Sample t-Test dengan taraf signifikansi 0,05. Hasil pengujian dapat dilihat di Tabel 5 .

Tabel 5. Uji Kesamaan Rata-rata Data Pretes

\begin{tabular}{ccc}
\hline \multicolumn{2}{c}{$\begin{array}{c}\text { Uji t untuk kesamaan } \\
\text { rata-rata }\end{array}$} & \multirow{2}{*}{ Keterangan } \\
\cline { 1 - 2 } $\mathrm{t}$ & Sig.(2-tailed) & \\
\hline 0,038 & 0,970 & Kemampuan \\
& awal sama \\
\hline$-0,570$ & 0,570 & \\
\hline
\end{tabular}

Selanjutnya kedua kelas diberikan perlakuan berbeda, yaitu pada kelas eksperimen diberikan model pembelajaran Inquiry Training menggunakan media PhET dan pada kelas kontrol diberikan model pembelajaran konvensional. Setelah perlakuan selesai, selanjutnya diberikan postes untuk melihat perbedaan keterampilan proses sains dan kemampuan berpikir logis siswa pada kedua kelas, hasilnya terdapat pada Tabel 6 .

Tabel 6. Data Postes

\begin{tabular}{ccc}
\hline Hasil Postes & Kelompok & Rerata \\
\hline Keterampilan & Eksperimen & 75,76 \\
\cline { 2 - 3 } Proses Sains & Kontrol & 67,68 \\
\hline Kemampuan & Eksperimen & 63,68 \\
\cline { 2 - 3 } Berpikir Logis & Kontrol & 58,53 \\
\hline
\end{tabular}

Selanjutnya dilakukan uji prasyarat hipotesis postes agar dapat dilakukan pengujian statistik dengan uji t untuk postes. Uji prasyarat hipotesis meliputi uji normalitas dengan uji Kolmogorov-Smirnov dan uji homogenitas menggunakan bantuan SPSS 16.0. Kelompok data dikatakan normal dan homogen jika nilai signifikansi lebih besar dari 0,05. Data hasil uji normalitas postes dapat dilihat pada Tabel 7. 
Tabel 7. Uji Normalitas Data Postes

\begin{tabular}{lcc}
\hline \multicolumn{1}{c}{ Uji Normalitas } & Sig. & Keterangan \\
\hline KPS Eksperimen & 0,200 & Normal \\
\hline KBL Eksperimen & 0,065 & Normal \\
\hline KPS Kontrol & 0,054 & Normal \\
\hline KBL Kontrol & 0,077 & Normal \\
\hline
\end{tabular}

Data hasil uji homogenitas postes dapat dilihat pada Tabel 8 .

Tabel 8. Uji Homogenitas Data Postes

\begin{tabular}{lcc}
\hline Uji Homogenitas & Sig. & Keterangan \\
\hline Postes KPS & 0,454 & Homogen \\
\hline Postes KBL & 1,000 & Homogen
\end{tabular}

Setelah dilakukan uji kelayakan data selesai dan terpenuhi, maka selanjutnya dilakukan pengujian hipotesis dengan menggunakan Independent Sample t-Test dengan bantuan SPSS 16.0. Dari data tes hasil keterampilan proses sains maupun kemampuan berpikir logis yang diperoleh kemudian dihitung menggunkan uji t untuk melihat perbedaan rata-rata hasil postes kedua kelompok sampel.

\section{Hipotesis Pertama}

Hipotesis pertama bertujuan untuk melihat perbedaan hasil postes keterampilan proses sains antara siswa kelas eksperimen yang diberikan pembelajaran dengan model pembelajaran Inquiry Training menggunakan media PhET dengan kelas kontrol yang diajar dengan pembelajaran konvensional. Pada hasil perhitungan SPSS 16.0 diperoleh uji statistik data hasil postes keterampilan proses sains siswa yang menggunakan model pembelajaran Inquiry Training menggunakan media PhET dan hasil keterampilan proses sains siswa yang menggunakan pembelajaran konvensional dapat dilihat pada Tabel 9 berikut.

Tabel 9. Uji-t Postes Keterampilan Proses Sains

\begin{tabular}{cccc}
\hline Hasil & $\begin{array}{c}\text { Nilai } \\
\text { Uji t }\end{array}$ & df & $\begin{array}{c}\text { Sig (2 } \\
\text { tailed) }\end{array}$ \\
\hline Postes KPS & 3,548 & 66 & 0,001 \\
\hline
\end{tabular}

Berdasarkan Tabel 9 diperoleh nilai Sig. sebesar 0,001. Maka dapat dikatakan bahwa hasil pengujian menolak Ho atau menerima $\mathrm{Ha}$ dalam taraf alpha 5\%. Dapat disimpulkan bahwa terdapat perbedaan yang signifikan pada keterampilan proses sains siswa yang diajarkan dengan model Inquiry Training menggunakan media PhET dengan siswa yang diajarkan dengan pembelajaran konvensional.

\section{Hipotesis Kedua}

Pada hasil perhitungan SPSS 16.0 diperoleh uji statistik data hasil postes kemampuan berpikir logis siswa yang menggunakan model pembelajaran Inquiry Training menggunakan media PhET dan hasil keterampilan proses sains siswa yang menggunakan pembelajaran konvensional dapat dilihat pada Tabel 10.

Tabel 10. Uji-t Postes Kemampuan Berpikir

\begin{tabular}{cccc}
\multicolumn{5}{c}{ Logis } \\
\hline Hasil & $\begin{array}{c}\text { Nilai } \\
\text { Uji t }\end{array}$ & df & $\begin{array}{c}\text { Sig (2 } \\
\text { tailed) }\end{array}$ \\
\hline Postes KBL & 2,306 & 66 & 0,024 \\
\hline Berdasarkan & Tabel & 10. & hasil uji \\
t
\end{tabular}
diperoleh nilai Sig.sebesar 0,024. Maka dapat dikatakan bahwa hasil pengujian menolak Ho atau menerima Ha dalam taraf alpha 5\%. Dapat disimpulkan bahwa terdapat perbedaan hasil kemampuan berpikir logis siswa yang diajarkan dengan model pembelajaran Inquiry Training menggunakan media PhET dengan kelas kontrol yang diajarkan dengan pembelajaran konvensional.

\section{PEMBAHASAN}

Setelah dilakukan pengujian hipotesis melalui uji kesamaan dua rata-rata (uji t) untuk mengetahui kesamaan kemampuan awal keterampilan proses sains pada kedua kelompok sampel, diperoleh $t_{\text {hitung }}$ sebesar 0,038 dan signifikansi sebesar 0,970. Signifikansi yang diperoleh lebih besar dari 0,05, maka dapat disimpulkan bahwa keterampilan proses sains awal siswa pada kelas eksperimen sama dengan keterampilan proses sains awal siswa pada kelas kontrol. Untuk nilai rata-rata pretest keterampilan proses sains siswa kelas eksperiman adalah 30,68 dan untuk nilai rata-rata pretest keterampilan proses sains siswa kelas kontrol adalah 30,62.

Setelah dilakukan pengujian hipotesis dengan Uji $t$ satu pihak untuk mengetahui pengaruh dari suatu perlakuan yaitu model pembelajaran inquiry training menggunakan media PhET terhadap keterampilan proses sains 
siswa, diperoleh $t_{\text {hitung }}$ sebesar 3,548 dan signifikansi sebesar 0,001. Signifikansi yang diperoleh lebih kecil dari 0,05, maka dapat disimpulkan bahwa terdapat perbedaan hasil keterampilan proses sains siswa pada kelas eksperimen dan kelas kontrol. Untuk nilai ratarata postest keterampilan proses sains kelas eksperimen adalah 75,67 sedangkan nilai ratarata postest keterampilan proses sains kelas kontrol adalah 67,68. Hal tersebut menunjukkan bahwa terdapat perbedaan keterampilan proses sains siswa yang diajarkan dengan model pembelajaran inquiry training menggunakan media PhET dan lebih baik daripada keterampilan proses sains siswa yang diajarkan dengan model pembelajaran konvensional. Maka pembelajaran dengan model pembelajaran inquiry training menggunakan media PhET dikatakan berpengaruh terhadap keterampilan proses sains siswa. Menurut penelitian Kurniawan \& Endah (2010) menyimpulkan bahwa keterampilan proses sains dapat dikembangkan dalam praktikum, keterampilan-keterampilan tersebut meliputi keterampilan merencanakan, keterampilan melaksanakan, dan keterampilan mengkomunikasikan Dalam penelitiannya membahas keterampilan proses sains yang dicapai mahasiswa, akan dikelompokkan berdasarkan pada komponen-komponen keterampilan yang dikembangkan. Nilai prosentase keterampilan merencanakan secara keseluruhan adalah 68,94\%. Berdasarkan indikator keberhasilan nilai prosentase tersebut mempunyai arti cukup. Sedangkan untuk nilai prosentase keterampilan melaksanakan secara keseluruhan adalah $58,82 \%$. Berdasarkan indikator keberhasilan nilai prosentase tersebut mempunyai arti kurang dari cukup. Nilai prosentase keterampilan mengkomunikasikan secara keseluruhan adalah $76,50 \%$. Berdasarkan indikator keberhasilan nilai prosentase tersebut mempunyai arti kurang dari baik.

\section{Kemampuan Berpikir Logis Siswa}

Pada penelitian ini, setelah dilakukan pengujian hipotesis melalui uji kesamaan dua rata-rata (uji t) untuk mengetahui kesamaan kemampuan awal kemampuan berpikir logis siswa pada kedua kelompok sampel, diperoleh $t_{\text {hitung }}$ sebesar $-0,570$ dan signifikansi sebesar 0,570. Signifikansi yang diperoleh lebih besar dari 0,05, maka dapat disimpulkan bahwa kemampuan berpikir logis awal siswa pada kelas eksperimen sama dengan kemampuan berpikir logis awal siswa pada kelas kontrol. Untuk nilai rata-rata pretest kemampuan berpikir logis siswa kelas eksperimen adalah 50,29 dan untuk nilai rata-rata pretest kemampuan berpikir logis siswa kelas kontrol adalah 51,57.

Setelah dilakukan pengujian hipotesis dengan Uji $t$ satu pihak untuk mengetahui pengaruh dari suatu perlakuan yaitu model pembelajaran inquiry training menggunakan media PhET terhadap kemampuan berpikir logis siswa, diperoleh $t_{\text {hitung }}$ sebesar 2,306 dan signifikansi sebesar 0,024. Signifikansi yang diperoleh lebih kecil dari 0,05, maka dapat disimpulkan bahwa terdapat perbedaan hasil kemampuan berpikir logis siswa pada kelas eksperimen dan kelas kontrol. Untuk nilai ratarata postes kemampuan berpikir logis siswa kelas eksperimen adalah 63,68 sedangkan nilai rata-rata postes kemampuan berpikir logis siswa kelas kontrol adalah 58,53.

Sebelumnya Purwanto (2012) telah melakukan penelitian quasi-eksperimen dengan tujuan untuk mengetahui pengaruh model pembelajaran inquiry terhadap kemampuan berpikir logis pada siswa kelas X SMA Negeri 8 Kota Bengkulu. Pengambilan data penelitian dengan menggunakan tes hasil belajar kognitif berupa soal pilihan ganda beralasan pada konsep listrik dinamis. Analisis data menggunakan uji-t dua sampel independen, diperoleh hasil skor rata-rata postes kelas eksperimen berbeda secara signifikan dengan rata-rata skor postes kelas kontrol dengan $t_{\text {hitung }} 2,139>t_{\text {tabel }}$ 1,670 pada taraf signifikan $95 \%$. Hasil penelitian menunjukkan bahwa terdapat pengaruh penerapan model inkuiri terbimbing terhadap kemampuan berpikir logis siswa kelas $\mathrm{X}$ di SMA N 8 Kota Bengkulu.

Penelitian yang dilakukan Ismail dan Jusoh (2001) mengungkapkan bahwa baik keterampilan proses sains dan kemampuan 
berpikir saling terkait. Diharapkan melalui pembelajaran aktif, siswa dapat memperoleh keterampilan proses dengan baik serta mengembangkan keterampilan berpikir mereka.

\section{KESIMPULAN}

Berdasarkan hasil penelitian dan pembahasan dapat disimpulkan sebagai berikut:

1. Terdapat Perbedaan hasil postes keterampilan proses sains siswa yang diberi pembelajaran dengan model Inquiry training menggunakan media PhET dengan siswa yang diberi pembelajaran konvensional. Kelas ekperimen memperoleh rata-rata 75,76 dan kelas kontrol memperoleh ratarata 67,68. Model pembelajaran Inquiry training menggunakan media PhET lebih baik dalam meningkatkan keterampilan proses sains siswa daripada pembelajaran konvensional.

2. Terdapat Perbedaan hasil postes kemampuan berpikir logis siswa yang diberi pembelajaran dengan model Inquiry training menggunakan media PhET dengan siswa yang diberi pembelajaran konvensional. Kelas ekperimen memperoleh rata-rata nilai 63,68 dan kelas kontrol memperoleh rata-rata 58,53. Model pembelajaran Inquiry training menggunakan media PhET lebih baik dalam meningkatkan kemampuan berpikir logis siswa daripada pembelajaran konvensional.

\section{DAFTAR PUSTAKA}

Dahar,R.W. 1991. Teori-Teori Belajar. Jakarta: Erlangga.

Damanik, D. P. 2013. Analisis Kemampuan Berpikir Kritis dan Sikap Ilmiah Pada Pembelajaran Fisika Menggunakan Model Pembelajaran Inquiry Training dan Direct Instruction. Tesis Medan, Program Studi Pendidikan Fisika Pasca Sarjana Unimed.

Dimyati dan Mudjiono. 2009. Belajar dan Pembelajaran. Jakarta: Rineka Cipta.

Ismail, Z., C., and Jusoh, I. 2001. Relationship Between Science Process Skills And
Logical Thinking Abilities Of Malaysian Students, Journal of Science and Mathematics Education in s.e. Asia. Volume 25, Number 2. 67-77

Joyce, Bruce. 2011. Models Of Teaching (Model-Model Pengajaran Edisi-8). Terjemahan oleh Achmad Fawaid dan Ateilla Mirza. 2009. Yogyakarta: Pustaka Pelajar.

Kurniawan, W. \& Endah, D. 2010. Pembelajaran fisika dengan metode inquiry Terbimbing untuk mengembangkan Keterampilan proses sains. JP2F, Volume 1 Nomor 2 September 2010, 149-154.

Legimin, 2010. Pengaruh Model Pembelajaran dan Kemampuan Berpikir Logis Terhadap Hasil Belajar Matematika Siswa SMA Negeri 1 Kuala. Tesis Program Studi Pendidikan Fisika PascaSarjana UNIMED Medan.

Purwanto, A. 2012. Kemampuan berpikir Logis Siswa SMA Negeri 8 Kota Bengkulu Dengan Menerapkan Model Inquiry Terbimbing Dalam Pembelajran Fisika. Jurnal Exacta, Volume. 10, Nomor 2, 133-135.

Rao, B. \& Kumari, U. N. 2012. Science Proccess Skills of School Students. New Delhi: Aurora Offset.

Rohman, A. 2014. Epistemologi dan Logika. Yogyakarta: Aswaja Pressindo.

Sani, R. A. 2012. Pengembangan Laboratorium Fisika. Medan: Unimed Press.

Sutama, I., N., dan Putu I., B., 2014. Pengaruh Model Pembelajaran Inkuiri Terhadap Ketrampilan Berpikir Kritis Dan Kinerja Ilmiah Pada Pelajaran Biologi Kelas XI IPA SMA Negeri 2 Amlapura, e-Journal Program Pascasarjana Universitas Pendidikan Ganesha Program Studi IPA. Volume 4, Nomor 3, 1-14.

Trianto, 2009. Mendesain Model Pembelajaran Inovativ Progresif. Jakarta: Kencana Prenada Media Group. 